\title{
PENGARUH KEPEKATAN NUTRISI DAN BERBAGAI MEDIA TANAM PADA PERTUMBUHAN SERTA PRODUKSI BAWANG MERAH (Allium ascalonicum L) DENGAN HIDROPONIK NFT
}

\author{
Effect of Concentration of Nutrition and Various Planting Media on Growth and \\ Production of Shallots (Allium Ascalonicum L) with NFT Hydroponics
}

\author{
Shamora Della Hoya Simbolon, Ernita, M.Nur \\ Program Studi Agroteknologi, Fakultas Pertanian Universitas Islam Riau \\ Jl. Kaharuddin Nasution No.113Pekanbaru. 28284. \\ Telp : 0761-674681;Fax : 0761-674681 \\ [Diterima: Mei 2018; Disetujui: Juli 2018]
}

\begin{abstract}
The purpose of this study was to investigate the interaction of the application of $\mathrm{AB}$ Mix nutrition and growing media on the growth and production of Shallots (Allium ascalonicum L.) on NFT hydroponics. This study uses a ]Compound Plot Design in the form of a Completely Randomized Design consisting of the main plot, namely the nutrient concentration of $A B$ Mix $(N)$ and subplots of planting media (M). Nutrition AB Mix consists of 4 treatment levels, 600, 1200, $1800,2400 \mathrm{ppm} / 1$ water and various planting media treatments consisting of 3 levels, namely husk, cocopeat, and sawdust charcoal media. Each experimental unit consisted of 4 plants and 2 plants used as samples. The parameters observed were as follows: plant height, harvest age, number of tubers, wet tuber weight, dry tuber weight, tuber weight per tuber, tuber weight loss. The observations of each treatment were statistically analyzed and continued with further tests of Honest Significant Difference at the 5\% level. The interaction of the application of $\mathrm{AB}$ Mix nutrition and planting media had a real effect on all parameters, with the best $\mathrm{AB}$ Mix $1800 \mathrm{ppm}$ and cocopeat growing media. The effect of $\mathrm{AB}$ Mix main plot has significantly affected all parameters observed with the best treatment of AB Mix $1800 \mathrm{ppm}$ nutrition. The effect of subplot planting media significantly affected all parameters of observation with the best treatment of cocopeat growing media
\end{abstract}

Keywords: AB Mix, Shallots, NFT hydroponics

ABSTRAK

Tujuan penelitian adalah untuk mengetahui interaksi aplikasi nutrisi AB Mix dan media tanam terhadap pertumbuhan serta produksi bawang merah (Allium ascalonicum.L) secara hidroponik NFT. Penelitian ini menggunakan Rancangan Petak Terbagi dalam bentuk Rancangan Acak Lengkap yang terdiri dari petak utama yaitu konsentrasi nutrisi AB Mix (N) dan anak petak media tanam (M). Pemberian Nutrisi AB Mix terdiri dari 4 taraf perlakuan yaitu 600, 1200, 1800, $2400 \mathrm{ppm} / \mathrm{l}$ air dan perlakuan berbagai media tanam terdiri dari 3 taraf yaitu media arang sekam, cocopeat, serbuk gergaji. Setiap satuan percobaan terdiri dari 4 tanaman dan 2 tanaman dijadikan sebagai sampel. Parameter yang diamati sebagai berikut: tinggi tanaman, umur panen, jumlah umbi, berat umbi basah, berat umbi kering, berat umbi perrumbi, susut bobot umbi. Hasil pengamatan dari masing-masing perlakuan dianalisis secara statistik dan di lanjutkan dengan uji lanjut Beda Nyata Jujur pada taraf $5 \%$. Interaksi aplikasi nutrisi AB Mix dan media tanam memberikan pengaruh nyata terhadap semua parameter, dengan pemberian terbaik AB Mix $1800 \mathrm{ppm}$ dan media tanam cocopeat. Pengaruh petak utama nutrisi $\mathrm{AB}$ Mix berpengaruh nyata terhadap semua parameter pengamatan dengan perlakuan terbaik nutrisi AB Mix 1800 ppm. Pengaruh anak petak media tanam berpengaruh nyata terhadap semua parameter pengamatan dengan perlakuan terbaik media tanam cocopeat

Kata Kunci: AB Mix, Bawang Merang, Hidroponik NFT 


\section{PENDAHULUAN}

Bawang merah merupakan tanaman sayuran semusim yang sangat populer dikalangan masyarakat, terutama bagi orang yang banyak terlibat dalam menyajikan makanan. Walaupun hanya sebagai pelengkap, bawang merah tidak dapat diabaikan begitu saja, karena hampir setiap masakan yang dihidangkan tidak terlepas dari kehadiran bawang merah. Selain sebagai bumbu penyedap pada makanan, bawang merah juga dapat sebagai obat tradisional.

Menurut Napitupulu dan Winarto (2010) bahwa tanaman bawang merah merupakan komoditas sayuran yang penting karena mengandung gizi tinggi. Setiap $100 \mathrm{~g}$ bawang merah mengandung 39 kalori, $15 \mathrm{mg}$ protein, $0,30 \mathrm{~g}$ lemak, 9,20 g karbohidrat, $50 \mathrm{mg}$ vitamin $A, 0,30 \mathrm{mg}$ vitamin $B, 200 \mathrm{mg}$ vitamin C, $36 \mathrm{mg}$ kalsium, $40 \mathrm{mg}$ fosfor dan $20 \mathrm{~g}$ air.

Produksi bawang merah di Indonesia pada tahun 2013 produksinya 1.010 .733 ton/tahun mengalami kenaikan pada tahun 2014 dengan produksinya 1.233 .984 ton/tahun sedangkan pada tahun 2015 mengalami penurunan dengan produksi 1.229.184 ton/tahun.Untuk Provinsi Riau pada tahun 2013 total produksinya 12 ton/tahun mengalami kenaikan pada tahun 2014 dengan total produksi 59 ton/tahun dan pada tahun 2015produksi bawang merah di Riau mengalami kenaikan produksi 140 ton/tahun (Anonimus, 2016).

Pemenuhan bawang merah Provinsi Riau masih bergantung dari daerah lain yaitu berasal dari Provinsi Sumatra Barat, Jawa maupun dari Sumatara Utara. Sementara peranan bawang merah sebagai kebutuhan rumah tangga masih belum bisa digantikan oleh rempah-rempah lainnya. Ketika terjadi bencana alam dari sumber-sumber penghasil bawang merah yang akan masuk ke Riau khusunya daerah kampar, akan berdampak terjadinya kenaikan harga bawang merah di pasaran. Upaya untuk mengurangi ketergantungan masyarakat kota Pekanbaru akan komoditi ini perluadanya pengembangan tanaman bawang merah melalui teknik budidaya yang optimal.

Salah satu masalah yang dihadapi oleh petani dalam meningkatkan produksi bawang merah adalah penggunaan pupuk yang tidak seimbang, sehingga mengakibatkan rusaknya sifat fisik, kimia dan biologi tanah. Khusunya di Riau banyak terdapat tanah yang bermasalah sehingga budidaya bawang merah masih kurang efektif.

Sistem budidaya yang dapat menghasilkan produk yang berkualitas tinggi adalah teknologi hidroponik. Hidroponik adalah cara bercocok tanam tanpa menggunakan tanah melainkan menggunakan air sebagai suplai hara dan mineral terhadap pertumbuhan tanaman.

Nutrisi yang digunakan dalam hidroponik merupakan unsur hara berupa pupuk majemuk maupun tunggal baik itu makro maupun mikro yang di formulasikan, unsur makro biasanya di beri simbol pupuk A dan mikro di beri simbol dengan $B$ setelah diformulasikan. Nutrisi AB Mix merupakan nutrisi yang biasa digunakan dalam budidaya sistem hidroponik yang mengandung 16 unsur hara esensial yang diperlukan tanaman. Larutan hara makro dan mikro dalam $\mathrm{AB}$ Mix terdiri dari $\mathrm{NH}_{4} \mathrm{NO}_{3} 1.2$ $\mathrm{mmol} / \mathrm{l}, \quad \mathrm{KNO}_{3} \quad 9.5 \mathrm{mmol} / \mathrm{l}, \mathrm{Ca}\left(\mathrm{NO}_{3}\right) 2 \quad 5.4$ $\mathrm{mmol} / \mathrm{l}, \mathrm{MgSO}_{4} 2.4 \mathrm{mmol} / \mathrm{l}, \mathrm{K}_{2} \mathrm{SO}_{4} 4.4 \mathrm{mmol} / \mathrm{l}$, $\mathrm{KH}_{2} \mathrm{PO}_{4} 1.5 \mathrm{mmol} / \mathrm{l}$. Larutan hara mikro terdiri dari Fe EDTA $15 \mu \mathrm{mol} / \mathrm{l}, \mathrm{MnSO}_{4} 10 \mu \mathrm{mol} / \mathrm{l}$, $\mathrm{ZnSO}_{4} 5 \mu \mathrm{mol} / \mathrm{l}, \mathrm{H}_{3} \mathrm{BO}_{3} 30 \mu \mathrm{mol} / \mathrm{l}, \mathrm{CuSO}_{4} 0.75$ $\mu \mathrm{mol} / \mathrm{l}, \quad \mathrm{NH}_{4}-\mathrm{MoO}_{4} \quad 0.5 \mu \mathrm{mol} / \mathrm{l} \quad$ (Agustina, 2004).

Selain dengan pemberian nutrisi yang tepat media tanam merupakan faktor yang paling berpengaruh dalam pertumbuhan dan hasil tanaman selada yang berkualitas. Media tanam yang baik bersifat porus dan ringan, mampu menjaga kelembaban dan menyimpan air. Media yang dapat digunakan dalam budidaya hidroponik sebagai pengganti fungsi tanah antaranya rockwooll, arang sekam, cocopeat, serbuk gergaji asalkan fungsi nya sama dengan tanah meskipun tidak seutuhnya sama. Nutrisi dan media yang baik akan menentukan hasil yang baik bagi tanaman hidroponik tersebut.

Berdasarkan latar belakang tersebut, maka penulis telah melakukan penelitian tentang "Pengaruh kepekatan nutrisi AB Mix dan media tanam pada pertumbuhan serta produksi bawang merah (Allium ascalonicum L.) dengan sisitem NFT". 


\section{BAHAN DAN METODE}

Penelitian ini telah dilaksanakan di Laboratorium Autoagronom Fakultas Pertanian Universitas Islam Riau, Jalan Kaharuddin Nasution, No. 113 Kelurahan Air Dingin, Kecamatan Bukit Raya Kota Pekanbaru. Penelitian ini dilaksanakan selama 3 bulan, terhitung mulai dari agustus sampai dengan bulan Oktober 2017.

Bahan yang digunakan dalam penelitian ini adalah bibit bawang merah (Lampiran 3), nutrisi AB Mix, cocopeat, arang sekam, serbuk gergaji, bayclin, plasti, spanduk. Alat yang digunakan adalah wadah nampan, talang NFT, mesin pompa air, netpot, EC meter, $\mathrm{pH}$ meter, handsprayer, ember, bak penampung air, timbangan analitik, kamera dan alat tulis.

Rancangan yang digunakan dalam percobaan ini adalah Rancangan Petak Terbagi dalam bentuk Rancangan Acak Lengkap yang terdiri dari petak utama yaitu nutrisi $\mathrm{AB}$ Mix (N) dan anak petak yaitu media tanam (M).
Pemberian Nutrisi AB Mix terdiri dari 4 taraf perlakuan dan perlakuan media tanam terdiri dari 3 taraf perlakuan, sehingga terdapat 36 kombinasi perlakuan dengan 3 kali ulangan. Dengan demikian penelitian ini terdiri dari 36 satuan percobaan dengan total tanaman 144 Setiap satuan percobaan terdiri dari 4 tanaman dan 2 tanaman dijadikan sebagai sampel.

\section{HASIL DAN PEMBAHASAN}

\section{Tinggi Tanaman (cm)}

Hasil pengamatan tinggi tanaman bawang merah, setelah dianalisis ragam menunjukkan bahwa pengaruh interaksi pemberian berbagai konsentrasi nutrisi AB Mix dan media tanam dan pengaruh utama nyata terhadap tinggi tanaman bawang merah. Rerata tinggi tanaman bawang merah setelah dilakukan uji lanjut BNJ taraf $5 \%$ dapat dilihat pada Tabel 1 .

Tabel 1. Rerata tinggi tanaman bawang merah dengan konsentrasi nutrisi AB Mix dan media tanam $(\mathrm{cm})$

\begin{tabular}{|c|c|c|c|c|}
\hline \multirow[b]{2}{*}{$\begin{array}{l}\text { Nutrisi AB Mix } \\
(\mathrm{ppm})\end{array}$} & \multicolumn{3}{|c|}{ Media Tanam (M) } & \multirow[b]{2}{*}{ Rerata } \\
\hline & $\begin{array}{c}\text { M1 } \\
\text { (arang sekam) }\end{array}$ & $\begin{array}{c}\mathrm{M} 2 \\
\text { (cocopeat) }\end{array}$ & $\begin{array}{c}\text { M3 } \\
\text { (serbuk gergaji) }\end{array}$ & \\
\hline $600(\mathrm{~N} 1)$ & $27,00 \mathrm{e}$ & $27,67 \mathrm{de}$ & 30,67 cde & $28,44 \mathrm{c}$ \\
\hline $1200(\mathrm{~N} 2)$ & $33,00 \mathrm{bc}$ & $34,67 \mathrm{bc}$ & $32,67 \mathrm{bc}$ & $33,44 \mathrm{~b}$ \\
\hline $1800(\mathrm{~N} 3)$ & $32,00 \mathrm{c}$ & $39,67 \mathrm{a}$ & $36,00 \mathrm{ab}$ & $35,89 \mathrm{a}$ \\
\hline $2400(\mathrm{~N} 4)$ & $31,67 \mathrm{~cd}$ & $34,00 \mathrm{bc}$ & $32,00 \mathrm{c}$ & $32,56 \mathrm{~b}$ \\
\hline Rerata (M) & $30,92 \mathrm{~b}$ & $34,00 \mathrm{a}$ & $34,83 \mathrm{a}$ & \\
\hline $\begin{array}{l}\mathrm{KK}(1)=2,85 \% \\
\mathrm{KK}(2)=3,99 \%\end{array}$ & \multicolumn{4}{|c|}{$\mathrm{BNJ} \mathrm{N}=1,25 \quad \mathrm{BNJ} \mathrm{M}=1,37 \quad \mathrm{BNJ} \mathrm{NM}=4,02$} \\
\hline
\end{tabular}

Angka-angka pada kolom dan baris yang diikuti huruf kecil yang sama tidak berbeda nyata menurut uji BNJ taraf 5\%.

Dari Tabel 1 dapat dilihat bahwa secara interaksi kepekatan larutan nutrisi AB Mix dan tedia tanam nyata pada tinggi tanaman. Tinggi tanaman tertinggi terdapat pada kombinasi perlakuan nutrisi 1800 ppm dengan media tanam cocopeat (N3M2) yaitu $39,7 \mathrm{~cm}$ dan tidak berbeda nyata dengan perlakuan konsentrasi 2400 ppm dan media serbuk gergaji (N3M3) dengan tinggi tanaman yaitu $36,0 \mathrm{~cm}$, tetapi berbeda dengan perlakuan lainnya. Tinggi tanaman terendah terdapat pada perlakuan konsentrasi 600 ppm dikombinasikan media arang sekam (N1M1) dengan tinggi tanaman yaitu $27,0 \mathrm{~cm}$.
Tinggi tanaman perlakuan N3M2 diduga karena kepekatan Nutrisi yang tepat dan media cocopeat mampu menjadi penopang dan penyimpan air yang baik sehingga kebutuhan nutrisi tersedia bagi tanaman bawang merah, hasil perakuan N3M3 dengan nutrisi 2400 ppm dan media tanam serbuk gergaji tidak berbeda nyata dikarenakan memiliki sifat yang sama yaitu mampu menyerap air yang banyak sehingga kebutuhan nutrisi terpenuhi. Pada perlakuan N1M1 memberikan pengaruh yang terendah terhadap pertumbuhan tinggi tanaman. Rendahnya pertumbuhan tinggi tanaman pada perlakuan N1M1 dikarnakan rendahnya nutrisi yang diberikan sehingga pembentukan vegetatf 
terganggu dan media arang sekam tidak mampu menopang tanaman menyebabkan tanaman tumbang dan mudah patah.

Sutiyoso(2003), menyatakan bahwa larutan nutrisi merupakan faktor penting untuk pertumbuhan dan kualitas hasil tanaman hidroponik, sehingga harus tepat dari segi jumlah komposisi ion nutrisi dan suhu. Larutan nutrisi ini dibagi dua, yaitu unsur makro dan unsur mikro. Unsur makro dibutuhkan tanaman dalam jumlah yang banyak yaitu nitrogen $(\mathrm{N})$, fosfor (P), kalium (K), kalsium (Ca), magnesium $(\mathrm{Mg})$ dan sulfur $(\mathrm{S})$. Unsur mikro dibutuhkan dalam jumlah sedikit yaitu besi $(\mathrm{Fe})$, mangan $(\mathrm{Mn})$, tembaga $(\mathrm{Cu})$, seng $(\mathrm{Zn})$, boron (B) dan molybdenum (Mo). Apabila tanaman kekurangan unsur makro dan mikro akan berpengaruh langsung terhadap pertumbuhan dan produksi tanaman.

Konsentrasi nutrisi pada umumnya merupakan bagian penting dalam pertumbuhan tanaman. Pada tanaman bawang merah konsentrasi nutrisi anjuran yaitu 1200-1800 ppm sampai panen namun kita bisa melakukan peningkatan sesuai kondisi tanaman yang kita tanam (Fajjriyah, 2007).

Menurut Mardawilis (2004), setiap tanaman membutuhkan Nitrogen, Kalium, dan Fosfor yang optimal dalam pertumbuhannya agar hasil yang diinginkan juga optimal. Terjadinya pertambahan tinggi tanaman disebabkan karena adanya peristiwa pemanjangan sel yang didominasi pada bagian pucuk, pada fase inilah unsur hara Nitrogen, Fosfor dan Kalium berperan dalam tanaman. Semakin terpenuhi konsentrasi nutrisi yang dibutuhkan maka akan berpengaruh baik.

\section{Umur Panen}

Hasil pengamatan umur panen bawang merah setelah dilakukan analisis ragam memperlihatkan bahwa pengaruh interaksi maupun pengaruh utama Kepekan nutrisi dan media tanam nyata terhadap umur panen. Rerata umur panen setelah dilakukan uji BNJ pada taraf 5\% dapat dilihat pada tabel 2.

Tabel 2. Rerata umur panen bawang merah dengan konsentrasi nutrisi AB Mix dan media tanam (hst)

\begin{tabular}{lcccc}
\hline \multirow{2}{*}{$\begin{array}{c}\text { Nutrisi AB Mix } \\
(\mathrm{ppm})\end{array}$} & \multicolumn{3}{c}{ Media Tanam $(\mathrm{M})$} & \multirow{2}{*}{ Rerata } \\
\cline { 2 - 4 } & $\begin{array}{c}\text { M1 } \\
\text { (arang sekam) }\end{array}$ & $\begin{array}{c}\text { M2 } \\
\text { (cocopeat) }\end{array}$ & $\begin{array}{c}\text { M3 } \\
\text { (serbuk gergaji) }\end{array}$ & \\
\hline $600(\mathrm{~N} 1)$ & $63,00 \mathrm{~d}$ & $61,67 \mathrm{bcd}$ & $62,67 \mathrm{~cd}$ & $62,44 \mathrm{bc}$ \\
$1200(\mathrm{~N} 2)$ & $61,00 \mathrm{bc}$ & $61,33 \mathrm{bcd}$ & $61,33 \mathrm{bcd}$ & $61,22 \mathrm{~b}$ \\
$1800(\mathrm{~N} 3)$ & $60,00 \mathrm{ab}$ & $59,00 \mathrm{a}$ & $61,00 \mathrm{bc}$ & $60,00 \mathrm{a}$ \\
$2400(\mathrm{~N} 4)$ & $62,67 \mathrm{~cd}$ & $62,67 \mathrm{~cd}$ & $62,33 \mathrm{~cd}$ & $62,56 \mathrm{c}$ \\
\hline Rerata & $61,67 \mathrm{a}$ & $61,17 \mathrm{a}$ & $61,83 \mathrm{~b}$ & \\
\hline KK(1) $=1,24 \%$ & & BNJ N = 1,03 BNJ M=0,65 BNJ NM=1,90 & \\
KK(2)=1,00\% & & &
\end{tabular}

Angka-angka pada kolom dan baris yang diikuti huruf kecil yang sama tidak berbeda nyata menurut uji BNJ taraf 5\%.

Data pada Tabel 2, menunjukkan bahwa secara interaksi kepekatan nutrisi dan berbagai media tanam nyata terhadap umur panen bawang merah kombinasi kepekatan nutrisi 1800 ppm dan media tanam cocopeat (N3M2) merupakan perlakuan terbaik dengan umur panen tercepat yaitu 59,0 hari setelah tanam (hst) dan tidak berbeda dengan perlakuan kepekatan nutris $1800 \mathrm{ppm}$ dan media arang sekam (N3M1) dengan umur panen 60 hst. Umur panen terlama dihasilkan oleh kepekatan nutrisi $600 \mathrm{ppm}$ dan media tanam arang sekam (N1M1) dengan umur panen yaitu 63 hari setelah tanam.
Cepatnya umur panen pada perlakuan N3M2 dibandingkan dengan perlakuan lainnya hal ini disebabkan pemberian Nutrisi dengan kepekatan $1800 \mathrm{ppm}$ dan media tanam cocopeat (N3M2) telah memenuhi kebutuhan unsur hara tanaman, sehingga mampu meningkatkan metabolisme dalam jaringan tanaman yang akibatnya tanaman lebih memacu pertumbuhan vegetatif untuk memasuki pertumbuhan generatif khususnya dalam mempercepat masa panen dan pada media cocopeat mampu menyimpan air lebih banyak sehingga kebutuhan unsur hara terpenuhi. Nutrisi AB Mix memiliki kandungan unsur hara makro dan 
mikro yaitu monokalium phospat, MKP, $\mathrm{KH} 2 \mathrm{PO} 4$, dengan $\mathrm{K}$ sebesar $21 \%$ dan P $23 \%$ yang berperan penting bagi tanaman dalam peningkatan pertumbuhan tanaman bawang.

Lingga (2002), menyatakan bahwa unsur hara makro tanaman terutama unsur hara nitrogen merupakan unsur hara utama untuk mendorong pertumbuhan vegetatif tanaman dalam pembentukan daun dan membuat cadangan makanan dengan pemberian nitrogen dengan dosis yang tepat.

Menurut Hardjowigeno (2003), bahwa nitrogen diperlukan tanaman untuk memproduksi protein dan bahan-bahan penting lainnya dalam proses pembentukan sel-sel serta berperan dalam pembentukan klorofil. Adanya klorofil yang cukup pada daun akan meningkatkan kemampuan daun dalam menyerap cahaya matahari sehingga proses fotosintesis meningkat yang kemudian menghasilkan bahan organik sumber energi yang diperlukan sel-sel untuk melakukan aktifitas pembelahan dan pembesaran sel.

\section{Jumlah umbi (Umbi)}

Hasil pengamatan Jumlah Umbi Per rumpun bawang merah setelah dilakukan analisis ragam memperlihatkan bahwa pengaruh interaksi maupun utama Kepekatan nutrisi dan media tanam nyata terhadap jumlah umbi per rumpun. Rerata jumlah umbi setelah dilakukan uji BNJ pada taraf 5\% dapat dilihat pada tabel 3.

Tabel 3. Rerata jumlah umbi per rumpun bawang merah dengan kepelatan nutrisi AB Mix dan media tanam $(\mathrm{g})$

\begin{tabular}{ccccc}
\hline \multirow{2}{*}{$\begin{array}{c}\text { Nutrisi AB Mix } \\
(\text { ppm) }\end{array}$} & \multicolumn{3}{c}{ Media Tanam (M) } & Rerata \\
\cline { 2 - 4 } & $\begin{array}{c}\text { M1 } \\
\text { (arang sekam) }\end{array}$ & $\begin{array}{c}\text { M2 } \\
\text { (cocopeat) }\end{array}$ & $\begin{array}{c}\text { M3 } \\
\text { (serbuk gergaji) }\end{array}$ & \\
\hline $600(\mathrm{~N} 1)$ & $3,50 \mathrm{~b}$ & $3,67 \mathrm{~b}$ & $3,50 \mathrm{~b}$ & $3,56 \mathrm{~b}$ \\
$1200(\mathrm{~N} 2)$ & $4,00 \mathrm{~b}$ & $3,58 \mathrm{~b}$ & $4,00 \mathrm{~b}$ & $3,94 \mathrm{ab}$ \\
$1800(\mathrm{~N} 3)$ & $3,50 \mathrm{~b}$ & $5,83 \mathrm{a}$ & $3,83 \mathrm{~b}$ & $4,39 \mathrm{a}$ \\
$2400(\mathrm{~N} 4)$ & $4,17 \mathrm{~b}$ & $4,17 \mathrm{~b}$ & $3,83 \mathrm{~b}$ & $4.06 \mathrm{a}$ \\
\hline Rerata & $3,79 \mathrm{~b}$ & $4,38 \mathrm{a}$ & $3,79 \mathrm{~b}$ & \\
\hline KK(1) $=7,53 \%$ & & BNJ N $=0,40$ & BNJ M=0,52 & BNJ NM=1,54 \\
KK(2) $=12,54 \%$ & & &
\end{tabular}

Angka-angka pada kolom dan baris yang diikuti huruf kecil yang sama tidak berbeda nyata menurut uji BNJ taraf 5\%.

Data pada Tabel 3, menunjukkan bahwa secara interaksi kepekatan nutrisi dan berbagai media tanam nyata terhadap jumlah umbi bawang merah. Kombinasi kepekatan nutrisi $1800 \mathrm{ppm}$ dan media tanam cocopeat (N3M2) merupakan perlakuan terbaik dengan jumlah umbi yaitu 5,83 umbi, dan berbeda nyata dengan perlakuan lainnya.

Tingginya pertumbuhan jumlah umbiN3M2 diduga karena perpaduan nutrisi 1800 ppm dengan media cocopeat yang sudah optimal dengan ketersediaan unsur hara yang dibutuhkan untuk pertumbuhan jumlah umbipadabawangmerah terpenuhi. Media cocopet memiliki pori mikro yang mempu menghambat gerakan air besar menyebabkan ketersediaan air tinggi, dibandingkan dengan media arang sekam yang memiliki daya serap air yang lebih rendah dibandingkan media cocopeat dan media serbuk gergaji.

Media arang sekam memiliki porositas yang baik bagi perkembangan akar dan memiliki daya pegang air yang tinggi,Penggunaan arang sekam padi

selain mempercepat proses reklamasi dan meningkatkan pertumbuhan tanaman namun dalam penggunaannya harus melalui proses sterilisali baik dengan pengukusan atau perendaman dengan menggunakan fungisida untuk menekan pertumbuhan jamur dan melarutkan debu hasil pembakaran.

Larutan nutrisi sebagai sumber air dan mineral penting untuk pertumbuhan dan kualitas hasil tanaman hidroponik. Unsur nitrogen (N) sangat berpengaruh dalam pembentukan daun, batang dan anakan sehingga apabila digunakan dalam jumlah yang optimal 
maka akan meningkatkan pertumbuhan tanaman (Ruhnayat, 2007).

\section{Berat Umbi Basah Kering (g)}

Hasil pengamatan Berat Basah Umbi Per rumpun bawang merah setelah dilakukan analisis ragam memperlihatkan bahwa pengaruh interaksi maupun pengaruh utama Kepekan nutrisi dan media tanam nyata terhadap Berat Basah Umbi. Rerata BeratBasahUmbi Perrumpun setelah dilakukan uji BNJ pada taraf 5\% dapat dilihat pada tabel 4 .

Tabel 4. Rerata berat Umbi basah bawang merah kepekatan nutrisi AB Mix dan media tanam (g)

\begin{tabular}{|c|c|c|c|c|}
\hline \multirow[b]{2}{*}{$\begin{array}{l}\text { Nutrisi AB Mix } \\
\quad(\mathrm{ppm})\end{array}$} & \multicolumn{3}{|c|}{ Media Tanam (M) } & \multirow[b]{2}{*}{ Rerata } \\
\hline & $\begin{array}{c}\text { M1 } \\
\text { (arang sekam) }\end{array}$ & $\begin{array}{c}\text { M2 } \\
\text { (cocopeat) }\end{array}$ & $\begin{array}{c}\text { M3 } \\
\text { (serbuk gergaji) }\end{array}$ & \\
\hline $600(\mathrm{~N} 1)$ & $9,47 \mathrm{f}$ & 12,33 ef & 13,97 ef & $12,63 \mathrm{c}$ \\
\hline $1200(\mathrm{~N} 2)$ & 13,97 ef & $20,43 \mathrm{bcd}$ & $17,27 \mathrm{cde}$ & $17,22 \mathrm{~b}$ \\
\hline 1800 (N3) & $15,87 \mathrm{de}$ & $29,23 \mathrm{a}$ & $22,93 \mathrm{~b}$ & $22,68 \mathrm{a}$ \\
\hline 2400 (N4) & $15,90 \mathrm{de}$ & $22,00 \mathrm{bc}$ & $21,40 \mathrm{bc}$ & $21,77 \mathrm{a}$ \\
\hline Rerata (M) & $13,80 \mathrm{c}$ & $21,00 \mathrm{a}$ & $18,89 \mathrm{~b}$ & \\
\hline $\begin{array}{l}\mathrm{KK}(1)=13,97 \% \\
\mathrm{KK}(2)=9,82 \%\end{array}$ & \multicolumn{4}{|c|}{ BNJ $\mathrm{N}=3,37$ BNJ $\mathrm{M}=1,85 \quad \mathrm{BNJ} \mathrm{NM}=5,43$} \\
\hline
\end{tabular}

Angka-angka pada kolom dan baris yang diikuti huruf kecil yang sama tidak berbeda nyata menurut uji BNJ taraf $5 \%$.

Data pada Tabel 4, menunjukan bahwa interaksi kepekatannutrisidanberbagai media tanam berbedanyata terhadap berat umbi basah. Kombinasi pemberian pemberiannutrisi 1800 ppm dan media cocopeat (N3M2) merupakan perlakuan terbaik dengan berat umbi basah yaitu 29,23 g danberbeda dengan perlakuan lainnya, perlakuan yang menghasilkan berat umbi basah per rumpun terendah adalah pemberian nutrisi $\mathrm{AB}$ Mix $600 \mathrm{ppm}$ dan media arang sekam (N1M1) denganberat umbi basah9, $47 \mathrm{~g}$.

Lingkungan yang cukup akan mendukung pembentukan tanaman sehingga meningkatkan berat basah tanaman. Pada dasarnya tanaman bawang merah merupakan tanaman yang membutuhkan unsure hara kalium dalam pembentukan umbi, dimana nutrisi yang optimal akan menyumbangkan kalium yang dibutuhkan tanaman.

Unsur Kalium (K) dialam bisa diperoleh dari bahan organik salah satunya adalah dengan menggunakan sabut kelapa, sabut kelapa sendiri mempunyai kandungan Kalium cukup tinggi, namun untuk memperolehnya terlebih dahulu perlu diadakan proses yakni dibuat Mol sabut kelapa (Anonimus, 2017)

Penyerapan hara yang maksimal menyebabkan perkembangan sel-sel dalam tubuh tanaman karena akan terdiferiensiasi secara maksimal sehingga sistensi unsur hara menjadi energi lebih maksimal dan energi yang dihasilkan memanfaatkan untuk memacu pemanjangan sel meristem pucuk pada ujung daun lebih banyak. Banyaknya energi yang dihasilkan maka pendorongan sel meristem pucuk pada ujung daun menjadi maksimal sehingga pemanjangan sel dapat memepengaruhi bobot berat tanaman (Lingga, 2002).

Konsentrasi nutrisi pada umumnya merupakan bagian penting dalam pertumbuhan tanaman. Pada tanaman bawang merah konsentrasi nutrisi anjuran yaitu 1200-1800 ppm sampai panen namun kita bisa melakukan peningkatan sesuai kondisi tanaman yang kita tanam. Electrical Conductivity (EC) menunjukkan jumlah ion-ion yang terkandung dalam larutan nutrisi tersebut, 1 EC sama dengan 600 ppm (Fajjriyah, 2007).

\section{Berat Kering Umbi (g)}

Hasil pengamatan Berat Kering Umbi Per rumpun bawang merah setelah dilakukan analisis ragam memperlihatkan bahwa pengaruh interaksi maupun pengaruh utama Kepekatan nutrisi dan media tanam nyata terhadap Beratkering. Rerata beratkering setelah dilakukan uji BNJ pada taraf 5\% dapat dilihat pada tabel 5 . 
Tabel 5. Rerata berat kering umbi bawang merah dengan kepekatan nutrisi AB Mix dan media tanam (g)

\begin{tabular}{lcccc}
\hline \multirow{2}{*}{$\begin{array}{c}\text { Nutrisi AB Mix } \\
(\mathrm{ppm})\end{array}$} & \multicolumn{3}{c}{ Media Tanam (M) } & \multirow{2}{*}{ Rerata } \\
\cline { 2 - 4 } & $\begin{array}{c}\text { M1 } \\
\text { (arang sekam) }\end{array}$ & $\begin{array}{c}\text { M2 } \\
\text { (cocopeat) }\end{array}$ & $\begin{array}{c}\text { M3 } \\
\text { (serbuk gergaji) }\end{array}$ & \\
\hline $600(\mathrm{~N} 1)$ & $6,50 \mathrm{e}$ & $9,20 \mathrm{cde}$ & $8,83 \mathrm{cde}$ & $8,21 \mathrm{~d}$ \\
$1200(\mathrm{~N} 2)$ & $8,37 \mathrm{de}$ & $9,90 \mathrm{~cd}$ & $11,60 \mathrm{c}$ & $9,96 \mathrm{~cd}$ \\
$1800(\mathrm{~N} 3)$ & $11,77 \mathrm{c}$ & $24,97 \mathrm{a}$ & $14,67 \mathrm{~b}$ & $17,99 \mathrm{a}$ \\
$2400(\mathrm{~N} 4)$ & $10,87 \mathrm{~cd}$ & $17,13 \mathrm{~b}$ & $16,23 \mathrm{~b}$ & $14,74 \mathrm{~b}$ \\
\hline Rerata & $9,38 \mathrm{~b}$ & $15,30 \mathrm{a}$ & $13,50 \mathrm{~b}$ & \\
\hline KK(1) $=10,95 \%$ & & \multirow{2}{*}{ BNJ N $=1,9$ BNJ M=1,1 } & BNJ NM=3,34 \\
KK(2) $=8,50 \%$ & &
\end{tabular}

Angka-angka pada kolom dan baris yang diikuti huruf kecil yang sama tidak berbeda nyata menurut uji BNJ taraf 5\%.

Data pada Tabel 5, menunjukan bahwa pengaruh interaksi kepekatan nutrisi dan berbagai media tanam berbeda nyata terhadap berat umbi Kering. Kombinasi pemberian pemberian nutrisi $1800 \mathrm{ppm}$ dan media cocopeat (N3M2) merupakan perlakuan terbaik dengan berat umbi kering yaitu 24,97 g danberbeda dengan perlakuan lainnya, perlakuan yang menghasilkan berat umbi kering per rumpun terendah adalah pemberian nutrisi AB Mix 600ppm dan media arang sekam (N1M1) denganberat umbikering 6,50 g.

Media cocopeat dapat meningkatkan kemampuan tanaman dalam menyerap unsur hara atau nutrisi yang dibutuhkan tanaman yang mendukung menambah berat tanaman. Hal ini berbeda dengan media arang sekam yang menghasilkan berat kering umbi terendah dikarenakan arang sekam tidak melalui pengukusan sehingga penyakit maupun jamur yang terkandung didalamnya cepat menyebar menyerang tanaman dan sifat arang sekam mempunyai daya serap air yang lebih rendah dibandingkan media yang lainnya sehingga air yang mengandung nutrisi libih sedikit tersedia dibandingan media lain. Menurut Paat (2011), seluruh jenis unsur hara maupun air memegang peranan yang penting dalam tubuh tumbuhan dalam meningkatkan proses fisiologis dan morfologis sehingga dapat memacu peningkatan berat keseluruhan bagian (biomassa) tanaman.

Ketersediaan hara makro dan mikro bagi tanaman yang diberikan melalui nutrisi yang dialirkan ke tanaman merupakan hal yang sangat mendukung untuk pertumbuhan tanaman, terpenuhinya batas maksimum unsur hara yang diberikan pada tanaman merupakan faktor utama yang mempengaruhi pertumbuhan tanaman (Resima, 2001).

Berat umbi kering dipengaruhi oleh keadaan unsur hara dalam tanah serta penyerapan yang dilakukan oleh akar tanaman, jika unsur hara dalam tanah dalam keadaan seimbang, maka berat umbi tanaman lebih berat. Menunjukan tanaman tersebut tumbuh dan berkembang dengan baik (Aangad dan Suparti, 2005).

Tabel 6. Rerata berat umbi per umbi bawang merah dengan konsentrasi nutrisi AB Mix dan media tanam $(\mathrm{g})$

\begin{tabular}{|c|c|c|c|c|}
\hline \multirow[b]{2}{*}{$\begin{array}{l}\text { Nutrisi AB Mix } \\
\quad(\mathrm{ppm})\end{array}$} & \multicolumn{3}{|c|}{ Media Tanam (M) } & \multirow[b]{2}{*}{ Rerata } \\
\hline & $\begin{array}{c}\text { M1 } \\
\text { (arang sekam) }\end{array}$ & $\begin{array}{c}\mathrm{M} 2 \\
\text { (cocopeat) }\end{array}$ & $\begin{array}{c}\text { M3 } \\
\text { (serbuk gergaji) }\end{array}$ & \\
\hline $600 \quad(\mathrm{~N} 1)$ & $2,30 \mathrm{~b}$ & $2,37 \mathrm{~b}$ & $2,30 \mathrm{~b}$ & $2,32 \mathrm{~b}$ \\
\hline $1200(\mathrm{~N} 2)$ & $2.37 \mathrm{~b}$ & $2,77 \mathrm{~b}$ & $2,67 \mathrm{~b}$ & $2,60 \mathrm{~b}$ \\
\hline $1800(\mathrm{~N} 3)$ & $2,33 \mathrm{~b}$ & $4,80 \mathrm{a}$ & $4,13 \mathrm{a}$ & $3,76 \mathrm{a}$ \\
\hline $2400(\mathrm{~N} 4)$ & $2,40 \mathrm{~b}$ & $2,50 \mathrm{~b}$ & $2,63 \mathrm{~b}$ & $2,51 \mathrm{~b}$ \\
\hline Rerata & $2,35 \mathrm{c}$ & $3,11 \mathrm{a}$ & $2,93 \mathrm{~b}$ & \\
\hline $\begin{array}{l}\mathrm{KK}(1)=13,38 \% \\
\mathrm{KK}(2)=10,72 \%\end{array}$ & \multicolumn{4}{|c|}{$\mathrm{BNJ} \mathrm{N}=0,50 \quad \mathrm{BNJ} \mathrm{M}=0,32$} \\
\hline
\end{tabular}


Data pada Tabel 6, menunjukkan bahwa pengaruh interaksi kepekan nutrisi dan berbagai media tanam nyata terhadap beratumbi per umbi. Kombinasi kepekatan nutrisi 1800 ppm dan media cocopeat (N3M2) merupakan perlakuan terbaik dengan BeratUmbiperumbi yaitu $4,80 \mathrm{~g}$, tidak berbeda terhadap perlakuan nutrisi $2400 \mathrm{ppm}$ dan media tanam serbuk gergaji(N3M3)denganberatumbi 4,13g berbeda nyata dengan perlakuan lainnya. Berat umbi terendah dihasilkan oleh perlakuan nutrisi 600 ppm dan media arang sekam dengan berat umbi $2,30 \mathrm{~g}$.

Beratumbi per umbi di pengaruhi dengan pembentukan umbi yang sempurna dimana pembentukan umbi memerlukan unsure kalium yang tinggi. $\mathrm{AB}$ Mix memiliki kandungan kalium sebanyak $23 \%$ sehingga semakin tinggi nutrisi maka semakin banyak pula unsure kalium yang terkandung, namun jika kandungan $\mathrm{AB}$ mix yang terlampau tinggi akan meracuni tanaman tersebut.

Kalium berperan penting sebagai katalisator dalam perubahan protein menjadi asam amino, penyusunan karbohidrat, mengatur akumulasi dan translokasi karbohidrat yang terbentuk, aktifator enzim dalam proses fotositesis, meningkatkan ukuran biji, kualitas buah dan sayuran. Akan tetapi kalium dibutuhkan dalam jumlah banyak dibandingkan unsure lainnya pada tanaman umbiumbian (sumiati dan Gunawan, 2007).

Media cocopeat pada dasarnya memiliki kemampuan mengikat dan menyimpan air yang sangat kuat. Serbuk sabut kelapa (cocopeat) merupakan media yang memiliki kapasitas menahan air cukup tinggi. Media cocopeat memiliki pori mikro yang mampu menghambat gerakan air lebih besar sehingga menyebabkan ketersediaan air lebih tinggi (Lingga,2012).

\section{Susut bobot umbi (\%)}

Hasil pengamatan susut bobot umbi bawang merah setelah dilakukan analisis ragam memperlihatkan bahwa pengaruh interaksi maupun utama Kepekan nutrisi dan media tanam nyata terhadap susut bobot umbi. Rerata susut bobot umbi setelah dilakukan uji BNJ pada taraf 5\% dapat dilihat pada tabel 7 .

Data pada Tabel 7, menunjukkan bahwa pengaruh interaksi kepekatan nutrisi dan berbagai media tanam nyata terhadap bobot susut umbi. Kombinasi kepekatan nutrisi 1800 Ppm dan media cocopeat (N3M2) merupakan perlakuan terbaik dengan susut bobot umbi yaitu $18,53 \%$ dan tidak berbeda nyata dengan perlakuan N3M1 dan N3M3 dengan susut 20,13 $\%$. dan $20,53 \%$

Tabel 7. Rerata Pengamatan Susut Bobot Umbi dengan perlakuan Kepekatan Larutan Nutrisi dan Media Tanam (\%).

\begin{tabular}{|c|c|c|c|c|}
\hline \multirow[b]{2}{*}{ Nutrisi AB Mix (ppm) } & \multicolumn{3}{|c|}{ Media Tanam (M) } & \multirow[b]{2}{*}{ Rerata } \\
\hline & $\begin{array}{c}\text { M1 } \\
\text { (arang sekam) }\end{array}$ & $\begin{array}{c}\mathrm{M} 2 \\
\text { (cocopeat) }\end{array}$ & $\begin{array}{c}\text { M3 } \\
\text { (serbuk gergaji) }\end{array}$ & \\
\hline $600 \quad(\mathrm{~N} 1)$ & $24,43 \mathrm{~d}$ & $23,00 \mathrm{~cd}$ & $22,67 \mathrm{~cd}$ & $23,37 \mathrm{~b}$ \\
\hline $1200(\mathrm{~N} 2)$ & $21,50 \mathrm{bc}$ & $22,30 \mathrm{bc}$ & $23,0 \mathrm{~cd}$ & $22,27 \mathrm{~b}$ \\
\hline $1800(\mathrm{~N} 3)$ & $20,13 \mathrm{ab}$ & 18,53 a & $20,53 \mathrm{ab}$ & $19,73 \mathrm{a}$ \\
\hline $2400(\mathrm{~N} 4)$ & $23,47 \mathrm{~cd}$ & $23,37 \mathrm{~cd}$ & $23,77 \mathrm{~cd}$ & $23,53 \mathrm{~b}$ \\
\hline Rerata & $22,38 \mathrm{bc}$ & $21,80 \mathrm{a}$ & $22,49 \mathrm{c}$ & \\
\hline $\begin{array}{l}\mathrm{KK}(1)=6,66 \% \\
\mathrm{KK}(2)=2,95 \%\end{array}$ & & $=1,96 \mathrm{BN}$ & 96 BNJ NM= 2 & \\
\hline
\end{tabular}

Soedomo (2006) menyatakan, penyusutan umbi bawang merahsetelah penyimpanan umumnya 5-30\%. Bawang merah yangmemiliki nilai penyusutan terendah, memiliki daya simpan yangbaik serta tidak mudah busuk dan berkecambah selama prosespenyimpanan. Bawang merah yang memiliki nilai presentasepenyusutan rendah memiliki kandungan air dalam umbi yang ideal sehingga memiliki masa simpan yang lebih panjang.Kekerasantekstur serta jumlah padatan terlarut pada varietas bawang merahmerupakan hal yang mempengaruhi penyusutan umbi saatpenyimpanan dan kualitas simpan bawang merah. Bawang merah yang memiliki kekerasan 
yang baik serta jumlah padatan terlarut yang tinggi memiliki kandungan air umbi yang rendah sehinggasusut umbi tidak terlalu tinggi.

Terjadinya susut bobot selama penyimpanan adalah parameter mutu yang mencerminkan tingkat kesegaran. Semakin tinggi susut bobot, maka produk tersebut semakin berkurang tingkat kesegarannya. Peningkatan susut bobot bawang merah menjadi meningkat pada suhu yang lebih tinggi karena respirasi yang terjadi lebih tinggi. Rahmawati et al. (2009), menyatakan bahwa peningkatan suhu penyimpanan menyebabkan proses transpirasi semakin meningkat sehingga penguapan yang terjadi cukup besar yang mengakibatkan laju kehilangan air meningkat.

\section{KESIMPULAN}

Berdasarkan hasil penelitian ini dapat disimpulkan bahwa :

1. Hasil penelitian bawang merah dengan sistem hidroponik NFT menghasilkan produksi yang rendah dikarenakan tanaman terserang penyakit layu.

2. Interaksi kepekatan nutrisi $\mathrm{AB}$ Mix dan berbagai media tanam berpengaruh nyata terhadap tinggi tanaman, umur panen, jumlah umbi, berat basah umbi, berat kering umbi, berat umbi perumbi, susut bobot umbi. Perlakuan terbaik adalah konsentrasi larutan nutrisi AB Mix 1800 ppm dan media tanam cocopeat (N3M2).

3. Pengaruh utama konsentrasi larutan nutrisi $\mathrm{AB}$ Mix nyata terhadap tinggi tanaman, umur panen, jumlah umbi, berat umbi basah, berat umbi kering, berat umbi perumbi, susut bobot umbi. Perlakuan terbaik konsentrasi larutan nutrisi $\mathrm{AB}$ Mix 1800 ppm (N3).

4. Pengaruh utama konsentrasi larutan media tanam nyata terhadap tinggi tanaman, umur panen, jumlah umbi, berat umbi basah, berat umbi kering, berat umbi per umbi, susut bobot umbi. Perlakuan terbaik media tanam cocopeat (M2)

\section{DAFTAR PUSTAKA}

Agustina, L. 2004. Dasar Nutrisi Tanaman. Penerbit Rineka Cipta. Jakarta.
Anonimus. 2016. Luas Panen Bawang Merah Menurut Provinsi. http:www.Petanian .go.id/ap. Diakses 20 april 2017.

Fatjriyah.2007. Kiat sukses budidaya bawang merah.biogenesis. Yogyakarta. word.press.com. diakses pada tanggal 20 april 2017.

Lingga,P. 2012. Hidroponik, Bercocok Tanam Tanpa Tanah. Penebar Swadaya. Jakarta.

Mardawilis. 2004. Pemanfaatan tanaman optimal dan efisiensi penggunaan pupuk nitrogen pada beberapa variets jagung (Zea mays) dilahan kering. Jurnal Dinamika Pertanian. 19 (3) : 303-314.

Pranata. A. S. 2010. Meningkatkan hasil panen dengan pupuk organik.Agromedia Pustaka Jakarta.

Perwtasari, B. 2012. Pengaruh media tanaman dan media terhadap pertumbuhan dan hasil tanaman pakcoy (Brassica junca $\mathrm{L}$ ) dengan sisitem hidroponik. Agovigor. 5 (1): 14-25.

Prasetyono, H A, Adinugraha dan Suwandi. 2003. Keberhasilan stek pucuk Eukalyptus pada berbagai media dan hormon perangsang tumbuh. Jurnal pemuliaan tanaman hutan. 17 (1): 4-8

Resima. 2001. Pupukdan Cara PemupukanTanaman. PustakaBuana. Bandung.

Rukmana.

R. 2012. BawangMerahBudidayadanPengelolahan PascaPanen.Kaninus. Jakarta.

Samahudi. 2006. Pengaturan Komposisi dan Media dalam Budidaya Tanaman Tomat dengan Hidroponik. Skripsi Fakultas Pertanian UNS.

Sesmininggar, 2006.OptimasiKonentrasiLarutan Hara Tanaman Pak Choy (Brassica rapa L. cv. Group Pak Choy) PadaTeknologiHidroponikSistemTerapun g. Skripsi. Program StudiHortikultura. FakultasPertanian. IPB. Bogor.

Soedomo.2006.Pengaruh jenis kemasan dan daya simpan umbi bibit bawang merah terhadap pertumbuhan dan hasil di lapangan. Jurnal Hortiultura. 3 : 188189.

Sudirja. 2007. Bawang Merah http/www. Lablink.or.id//BawangMerah/Alternatif .html. diakses tanggal 20 April 2017. 
